\title{
Airbnb and its potential impact on the London housing market
}

\section{Zahratu Shabrina}

King's College London, UK

University College London, UK

\section{Elsa Arcaute}

University College London, UK

\author{
Michael Batty \\ University College London, UK
}

\begin{abstract}
This article identifies proxies which account for the impacts that the Airbnb platform is having on housing in Greater London. We identify these by analysing the relationships between possible Airbnb misuse and the attributes of housing in the same locations. We assume misuse when listings of entire properties within the Airbnb platform do not conform with local regulations and where hosts who offer such housing have multiple listings. In particular, we examine (I) the dwelling type based on building typology; (2) the type of housing tenure, whether it is owned or rented; and (3) the spatial distribution of changes in rent payable. Three important findings emerge from our analysis. First, based on 2018 data, we estimate that more than $2 \%$ of all properties in London, and up to $7 \%$ in some local areas are being misused through Airbnb as short-term holiday rentals. Second, the location of these particular Airbnb rentals is negatively correlated with the diversity of dwelling types and positively correlated with dwelling type such as an apartment (or flat) in areas of high private rental stock. Last, we show that a $100 \%$ increase in the density of possible Airbnb misuse can be associated with up to an $8 \%$ increase in unit rental price per-bedroom per-week, an equivalent to up to an average of $£ 90$ price increase per year. Finally, we discuss how this type of analysis can help build instruments to inform policies associated with the platform economy in relation to increasing polarisation in the London housing market.
\end{abstract}

\section{Keywords}

Airbnb misuse, dwelling types, entropy statistics, London housing market, rental values 


\section{摘要}

本文识别了一些指标, 这些指标说明了爱彼迎 (Airbnb) 平台对大伦敦住房市场的影响。 我们通过分析同一地段可能的爱彼迎误用与住房市场特征之间的关系来识别这些指标。 当爱彼迎平台内的整体房产放租信息不符合当地法规, 并且放租者有多个放租信息时, 我们推定存在误用。具体而言, 我们研究 (1) 住宅的建筑类型学分类; (2) 住房使用 权的类型, 是自有的还是租赁的; (3) 应付租金变化的空间分布。我们的分析得出了 三个重要发现。首先, 根据 2018 年的数据, 我们估计伦敦超过 $2 \%$ 的房产和一些分区高达 $7 \%$ 的房产作为短期度假出租物业而发生了爱彼迎误用。第二, 这些特定爱彼迎出租物业 的位置与住宅类型的多样性负相关, 与住宅类型（例如私人出租房屋存量高的地区的公 寓）正相关。最后, 我们表明可能的爱彼迎误用的密度增加 $100 \%$ 可能会导致每间卧室每 周的单位租赁价格增加 $8 \%$, 相当于每年平均增加 90 英镑。最后, 我们讨论这种类型的分 析如何有助于建立一些工具, 面对伦敦住房市场日益严重的两极分化, 这些工具能为与 平台经济相关的政策的制定提供参考。

\section{关键词}

爱彼迎误用、住宅类型、熵统计、伦敦住房市场、租赁价值

\section{Received March 2019; accepted September 2020}

\section{Introduction}

New information technologies are increasingly being used to underpin businesses and markets. The most high profile of these are those that are defined around 'platform' economies, typically any activities involving financial transactions that can be underpinned by the internet which bring buyers and sellers together as individuals (McAfee and Brynjolfsson, 2017; Parker et al., 2016). In the tourism sector, the best known of these is Airbnb, which puts those seeking shortterm accommodation in touch with those who have housing that matches this demand using the internet as the medium of transaction and interaction. This service is distorting traditional markets for housing and tourism because of its focus on the provision of platforms that link individual demand to individual supply together, often in real-time, with the company reaping financial profits. Apart from the way Airbnb acquires its revenues, one of the biggest problems so far with these kinds of service has been their lack of collective regulation (Stone, 2017). In this article, we will explore Airbnb and measure its possible impact on the housing market of a large world city, London.

London has undergone extreme distortions in its housing market over the last 200 years or more (Edwards, 2016; Watt and Minton, 2016) and there is evidence that the housing market might be affected by the rapid adoption of the home-sharing platform Airbnb (Barron et al., 2018; Garcia-López et al., 2019; Gutiérrez et al., 2017; Horn and Merante, 2017; Lee, 2016; Sheppard and Udell, 2018). London is an unequal city with rapidly rising rents and high house prices, wide disparities in its income distribution, distinct separation of social classes and multifaceted gentrification which is evident in its urban fabric (Davidson and Wyly, 2012; Hamnett, 2004; Watt and Minton, 2016). The nature of housing in London is already complex, and Airbnb is likely to be contributing to this complexity. However, global research surrounding Airbnb is highly contested, as some commentators identify Airbnb as invading the housing market 
(Barron et al., 2018; Garcia-López et al., 2019; Horn and Merante, 2017; Lee, 2016; Sheppard and Udell, 2018) and hotels (Zervas et al., 2016), while others find there are no apparent significant impacts and disruptions from Airbnb in terms of detracting from permanent housing and converting them to tourist accommodations (Snelling et al., 2016). Because the impact of Airbnb varies regionally and depends heavily on the socio-economic factors pertaining to the city itself (Quattrone et al., 2016), there is a challenge in drawing general conclusions regarding how Airbnb impacts the housing market globally.

This article aims to investigate the potential disruptions caused by Airbnb to the housing market by examining the possible misuse of Airbnb properties in London, correlating this with several housing attributes, including tenure, dwelling typology and the structure of rental price changes in London. We identify the possible misuse of Airbnb by separating those Airbnb accommodations that might not comply with the city-wide regulation, which limits holiday rentals being used for no more than 90 days annually (HM Government United Kingdom, 2015a, 2015b). We examine these associations which are mainly due to affordability issues and the related housing crisis, in addition to the rapid growth of peer-to-peer holiday rentals through platform economies, given by Airbnb in the present work.

\section{The complexity of the London housing market}

The housing problem in London is a manifestation of a complex system dominated by demand and supply imbalance, issues of taxation, subsidies and credits, the influx of global investments, as well as the impact of many different policies and politics surrounding the housing system (Gallent et al., 2017; Whitehead and Williams, 2011). Housing holds a fundamental place both in the economy and in society with dual roles related to human need (for shelter) and as an asset that holds a large proportion of a person's wealth (FTI Consulting LLP, 2012). For decades, the increase in the value of housing has been perceived as a sign of wealth, while a collapse in housing prices would indicate a significant disruption in the overall economics of how the city functions (Macfarlane, 2017). All this is particularly relevant to London. Prices continue to remain high, pricing out many Londoners, even those who receive aboveaverage incomes. The Office of National Statistics (ONS) found that, based on the ratio of house prices compared with gross annual earnings, many young first-time buyers would need to spend close to 13 times their annual earnings to acquire properties (Bentham, 2019). Although currently growing at their slowest rate in the last 10 years, house prices in London are still the highest in the UK by far, and first-time buyers find it difficult, if not impossible, to afford to purchase and own any accommodation (Elliott, 2018).

Historically, the housing market in the UK and London has not been able to create a balanced demand and supply, as there is an insufficient quantity and quality of supply. Despite recent efforts over the last decade, there has been a prolonged decline in new houses constructed since the 1970s, leading to a continuous housing shortfall and severe supply constraints (GLA, 2015; Watt and Minton, 2016). Thus, the massive annual development of new housing is now being prioritised over the coming decades. The London-wide Strategic Housing Market Assessment (SHMA) and Strategic Housing Land Availability Assessment (SHLAA) identified that London needs around 66,000 additional homes to be built annually with a total of 650,000 new homes needing to be built by 2029 (Mayor of London, 2018). A study by FTI Consulting LLP (2012) 
suggests that London is experiencing an asymmetry in prices (when house price increases and supply does not necessarily increase at the same rate) and considerable house price inelasticity (where a change in price is associated with a smaller percentage change in supply). London's population is projected to reach 10.2 million by 2039 (GLA Intelligence, Greater London Authority, 2015), and it seems unlikely that income will outpace house prices anytime soon (Macfarlane, 2017). The need for housing involves a diversified market demand as people's preferences over dwelling type, geographical location, occupancy and affordability vary (FTI Consulting LLP, 2012).

London housing supply faces several other challenges. These include the lengthy institutional process for planned development, where objections of a political nature often occur; procedural issues in obtaining land because of the asymmetry of land availability for developers within local authorities; and fundamental challenges involving land supply constraints in addition to financial hurdles (Holman et al., 2015). These challenges have shaped the housing market structure so that large firms dominate the local housing construction, creating a barrier of entry for small firms (FTI Consulting LLP, 2012). Without the proper steps, such as making the planning process more transparent and predictable, encouraging more land to be available for housing construction, and restructuring financial programmes to include firms of all sizes to operate with developers, expanding housing investment and increasing supply remains a major challenge (Holman et al., 2015).

Two major policies appear to have further exacerbated the problem of high house prices. The first is the 'Right to Buy' (RTB) policy through the Housing Acts in the 1980s which allowed people to buy discounted council housing. The policy is said to boost home-ownership but it has ultimately led to rising prices (Foster, 2015). By 2014, around 1.8 million property sales had been completed under the 'Right to Buy' scheme (Murie, 2015). Subsequently, these properties were often rented out, contributing to a new generation of private landlord-ism (Edwards, 2016; Slater, 2016). The second policy is the 'Help to Buy' schemes, introduced in October 2013, requiring buyers to purchase newly built houses from certified 'Help to Buy' builders, with evidence that this often helps inflate the price of the property while giving significant advantages to private developers (Jones, 2019).

\section{The growth of the private rented sector}

The growing unaffordability of the owneroccupation sector further increases the demand for the private rented sector (PRS), which is defined in the UK as properties owned by a landlord (individual, a property company, or institutional investor) and leased to a tenant. It is estimated that by $2030,40 \%$ of Londoners will be renting their homes (Future of London, 2017), a rise from $27 \%$ in 2016 (Trust for London, 2017) and $14 \%$ in 1991 (Mayor of London, 2015). The PRS is the least secure type of tenure, especially because of the UK's assured shorthold tenancy (AST). AST gives a landlord the right to remove tenants at two months notice after a fixed term of generally 612 months as well as exercising sharp increases in rent without warning (Judge and Tomlinson, 2018). Housing is considered affordable when a household spends no more than $30 \%$ of its income (Williams, 1992), but a study shows that one in seven privately renting tenants are spending more than $50 \%$ of their income on housing in Britain. This rises to up to $72 \%$ in Inner London based on 2015-2016 data, while only $2 \%$ of owner-occupiers spend more than those proportions for mortgages 
(Collinson, 2017; Trust for London, 2017). Many more people with families are renting their homes compared with the past. Based on the Office for National Statistics data in 2016, from a total of 4.5 million households in the UK that are living in the PRS, 1.8 million are families with children (Judge and Tomlinson, 2018), a distinct difference compared with the early 2000 s when there were only 600,000 of families with children living in the PRS (Judge and Tomlinson, 2018).

There was a meltdown in the UK property market in 2008 , house prices plunged by $20 \%$ over 16 months, taking an average of six years for prices to return to their precrash levels (Morrison, 2018). Nevertheless, parts of London remained unaffected by the fall in prices. 'Stamp duty' levied at increased levels up to a certain level of housing price was abolished in 2010 for first-time buyers and this was meant to stimulate house sales (Morrison, 2018). What subsequently followed was a surge of foreign investors flooding the prime property market. They were attracted by reduced property prices, making London the centre of a speculative market with the emergence of global corporate landlords (GCL), who bought properties as investments in what, by then, had become a new asset class (Beswick et al., 2016; Dorling, 2014). This trend has led to a big expansion in the private rented sector, which is expected to continue to increase over the future years (Colson, 2017). The private rented sector (PRS) has experienced accelerated growth as a consequence of this global financial crisis, with the proportion of new households who are renting privately increasing substantially, while existing households in the PRS are staying for a longer period (Kemp, 2015). Greater demand on the PRS is a result of slumps in spending, marked by a prolonged fall in the housingsector transactions, especially as financing mortgages have become increasingly more difficult to obtain. With a mortgage- tightened market, the 'Bank of mum and dad' or family loans act as the UK's ninthbiggest lender, funding more than 300,000 deals worth some $£ 77$ billion in housing finance in 2016, further extending the gap between those who can buy a home and those who can not (Walker, 2017). Also, trading up in the housing market, such as moving to a bigger home, has thus become increasingly difficult (Colson, 2017).

The crisis has exacerbated the UK's longstanding tensions in housing provision (Whitehead and Williams, 2011). Since 2008, new housing developments are facing increased risks and financial difficulties, reducing the market's confidence, lowering the willingness to buy despite reduced mortgages, and resulting in added restrictions on commercial and government lending (FTI Consulting LLP, 2012). This has hampered the availability of new supply, pushing prices up further generally. The credit crunch has transformed the nation's housing market, and to reach equilibrium, the UK housing market needs to increase supply by an average of $1 \%$ a year in general, and this number is higher in London (Kay, 2017).

\section{Airbnb: An additional contributor to the housing crisis?}

Even without adding Airbnb to the equation, London had undergone a long history of complex housing problems. Hilber (2015) found that for similar flats, the rental priceper-square metre in London is the second highest in the world, below Monaco and followed by Hong Kong, New York and Paris. Nowadays, the rapid growth of short-term holiday rentals such as Airbnb is feared to have worsened the housing crisis and affordability in many large cities, if not in most cities where there is a significant presence. Past research has examined Airbnb from the important perspective of exploring the effects of short-term rentals on the housing 
market, touching upon the possible impact of Airbnb with respect to the gentrification of neighbourhoods (Horn and Merante, 2017; Lee, 2016; Wachsmuth and Weisler, 2018). Based on the analysis by Wachsmuth and Weisler (2018), where the relationship between gentrification and short-term holiday rentals was examined, Airbnb appears to be forcing a new kind of rent gap. It allows the new revenue flow from short-term rentals through the platform, mainly in areas that are currently gentrifying or that are post-gentrified neighbourhoods.

Barron et al. (2018) analyse the overall effect of home-sharing in the USA in increasing house prices and rents by reallocating the housing supply from long-term to short-term rentals. In New York City, doubling the Airbnb activities is associated with an increase in property values between $6 \%$ and $11 \%$ (Sheppard and Udell, 2018). The trend of Airbnb as a possible contributor to the increase of rental rates is found in many international cities, such as Barcelona (Garcia-López et al., 2019), Los Angeles (Lee, 2016), Boston (Horn and Merante, 2017) and in Ireland (Lima, 2019). Moreover, there are many misuses through short-term holiday rentals in the housing market where hosts list more than one offer, for example in Berlin, as many as $0.30 \%$ of the total housing stock - some 5555 properties - are being misused as Airbnb listings (Schäfer and Braun, 2016). Other studies point out that Airbnb only comprises a small amount compared with the city-wide housing stock (Snelling et al., 2016), but these arguments do not take into account the fact that the housing stock and its occupants can be quite inert in the short term. Thus establishing causalities between rental changes and Airbnb presence is a challenging research question.

In this article, our prime focus is on assessing the scale and spatial distribution of Airbnb misuse - where Airbnb rentals do not conform to local regulations in which hosts own multiple listings. This study contributes to previous studies measuring Airbnb potential effects to the rental price increase, such as those by Barron et al. (2018), Horn and Merante (2017), Lee (2016), Sheppard and Udell (2018) and other scholars, by proposing a more targeted case of Airbnb misuse such as the analysis in Schäfer and Braun (2016). We do this by looking at the relationship between the level of misuse and the housing characteristics of the area, such as the diversity of dwelling types, the housing tenure and the rental distribution. This is especially important in a city such as London, where there is a rising urgency in developing affordable housing. Thus, any factor hindering residents from long-term housing needs to be investigated closely. To identify possible disruptions associated with the presence of Airbnb in London, we will explore a wide range of data sets:

1. Accommodation data from the $2011 \mathrm{UK}$ Population Census that refer to the types defined by the use of the dwellings according to the typology of the buildings.

2. Housing tenure data at LSOA and Borough level from the Census 2011 and the Office for National Statistics, respectively, which contain a summary of areas with the proportion of the type of home tenure in 2011 (LSOA) and in 2015 (Borough).

3. Airbnb data from Inside Airbnb (http:// insideairbnb.com) from 2015 to 2019. Listings refer to properties (including the entire property, private rooms or shared rooms) advertised on the Airbnb platform.

4. Housing supply data from the Valuation Office Agency (VOA). These data consist of the number of houses in each London LSOA (Lower Super Output Area), making up the total building stock available for London dwellings in 2015. 
5. Zoopla rental price data (Zoopla Limited, ${ }^{\odot} 2018$ from the Economic and Social Research Council. Zoopla Property Data. University of Glasgow Urban Big Data Centre), based on the 1.3 million available rental units at postcode level. For consistency throughout the analysis, the data have been preprocessed and aggregated at Borough level.

6. Net additional dwellings data from the Ministry of Housing, Communities and Local Government that calculate the addition from the new house building completions, gains or losses through conversions, changes of use (e.g. a conversion of a shop into a house or a barn), demolitions and other changes to the dwelling stock. We only incorporate data from 2015 to 2017 in this study.

7. Euclidean distance from Borough centroids to the city centre computed by measuring the differences in distance using the latitude and longitude of each borough centroid to the City of London (assumed as the city centre).

\section{Possible misuse of Airbnb properties}

There are different types of Airbnb rentals: an entire property - where the owners or hosts generally do not reside in the property - and a private/shared room where hosts are mostly present. Based on a study using semistructured interviews with Airbnb hosts who use the platform, one of the most repeated extrinsic motivations for renting through this peer-to-peer market, is to supplement rent or mortgage payments (Ikkala and Lampinen, 2015; Jefferson-Jones, 2014). This is also particularly true in the case of London, in which sharing accommodation or long-term sub-letting is a common practice to lessen the burden of the cost of renting or owning a house. This might be one of the reasons why Airbnb is very popular in cities where the cost of living is relatively high, mainly because it provides a channel for extra earnings.

Figure 1 provides a series of cumulative temporal snapshots of the Airbnb listings in 2018, that is, it shows the set of listings that were available (from the currently existing ones) for booking since specific years in Central London. There are more than 69,000 observations (Airbnb rentals) in London, from which about 50,000 (72\%) have at least one review, and these can be used as a proxy for active listings on the platform. Previous studies have discovered that one of the characteristics of Airbnb locations is the proximity to tourist attractions (Guttentag and Smith, 2017; Volgger et al., 2018). We thus show the key attractions in London based on Visit London 2015 Data which showcases the concentration of tourist attractions around the River Thames (far left of Figure 1). The maps show that very few Airbnb listings currently available were hosted since 2008, and they are all located to the north of the river (with a total of eight listings). The distribution of London tourist attractions is concentrated in the central areas north of the river, in alignment with the distribution of older Airbnb establishments. The previous study by Li et al. (2016) finds that the turnover of establishments on the Airbnb platform is relatively high, where $49 \%$ of the hosts exited the market after registering based on 18 months of observations of Airbnb between 2012 and 2013. They also found that non-professional hosts (those with only one listing instead of multiple listings) were $13.6 \%$ more likely to exit the market (Li et al., 2016).

In terms of regulating the platform economy, London has implemented Section 44 of the Deregulation Act (HM Government United Kingdom, 2015a) allowing Londoners to rent out properties for up to 90 cumulative days without planning permission, provided that there is no change of 


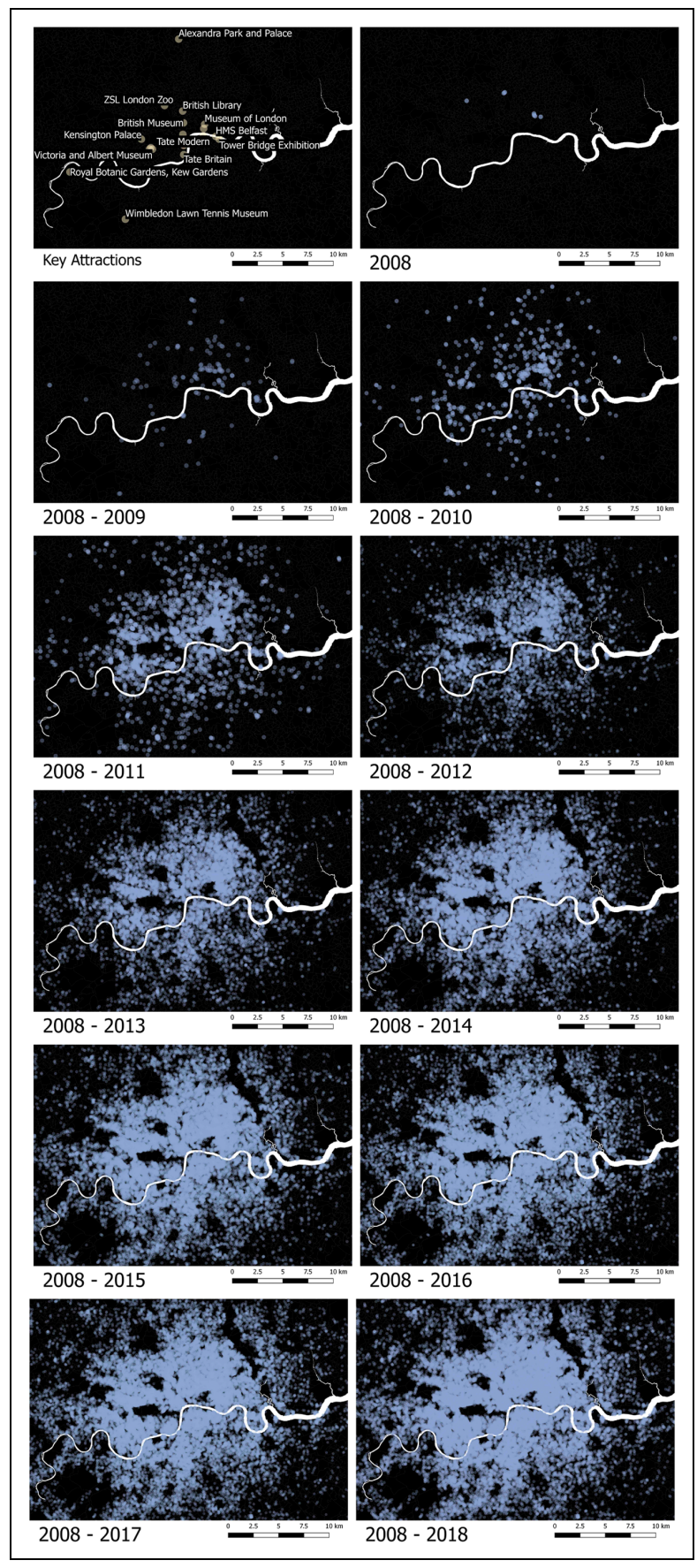

Figure I. The accummulation of Airbnb listings accessible for bookings in May 2018 according to the time of first listing. 


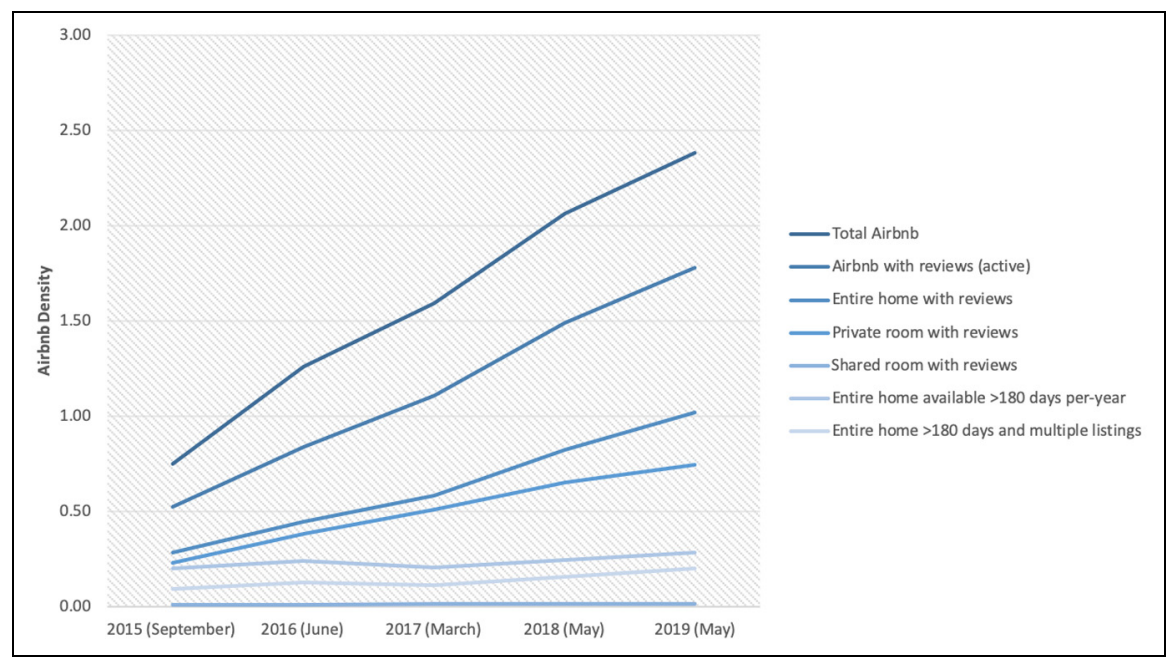

Figure 2. Percentage of Airbnb supply from 2015 to 2019 and possible misuse based on the number of days properties are being offered and whether hosts have multiple listings. In 2019 , almost $2.5 \%$ of the housing supply has been advertised as short-term rentals. The density of Airbnb in location is calculated by dividing the total number of Airbnb with the overall number of available dwellings representing the housing supply.

use (for which planning permission would be required) (HM Government United Kingdom, 2015b). This deregulation amended Section 25 of the Greater London Council (General Powers) Act 1973 and placed a cap on the number of days people can freely short-let their properties. This deregulation has left local institutions (such as councils) the resource-intensive task of managing and enforcing the new regulation, which is challenging as there is no formal notification process for short-term letting, nor transparency of usage at the platform level (Ferreri and Sanyal, 2018). The relaxation of the deregulation related to the platform economy might be one of the reasons why Airbnb has grown uncontrollably over the years.

The study by Schäfer and Braun (2016) analysed the misuse of Airbnb in Berlin by looking at the lettings not complying with the local regulation. In this work, similarly, we identify the supply of Airbnb hosts complying with the current 90 days limit regulation and those who do not.

In the case of London, we define possible misuse using the following criteria:

- Entire property listings that are offered for more than 180 days cumulatively in one year, assuming that the occupancy rate is $50 \%{ }^{1}$ These have a higher chance of being booked for more than 90 days annually (which violates the 90 days limit for letting properties as holiday rentals in London).

- Airbnb misuse are entire property listings that are offered for more than 180 days cumulatively in one year in which hosts have multiple (two or more) listings.

From Figure 2 we can see that the proportion of Airbnb compared with the total housing supply, has grown from $0.75 \%$ (25,000 properties) in 2015 to $2.38 \%(80,000$ 
properties) in 2019. Such growth is continuously increasing, as Airbnb keeps expanding in terms of their supply and more people participate in the platform over the years. Figure 2 shows the proportion of Airbnb in general and the possible misuse over five years. It examines the proportion of entire Airbnb properties according to the annual availability (if listings are available for more than 180 days), as well as whether the hosts have multiple listings - indicating possible misuse. Based on the Valuation Office Agency data, there are approximately 3.4 million dwellings in London, and compared with this number, houses advertised through the platform comprise quite a small percentage of the overall housing supply. This number might not appear to be very significant. This is due to the concentration of Airbnb in some areas, leading to some regions experiencing more pressure from Airbnb conversions compared with others.

To gain a finer understanding of the distribution of Airbnb listings according to their types, Figure 3 a provides a snapshot of the Airbnb data for May 2018 organised into totals at the Lower Super Output Area level (LSOAs), which typically have an average population of around 1500 in London. London is a fairly mono-centric city in terms of its activities and employment centres (Buck et al., 2013), so we would wish to see if this is also the case for the Airbnb distribution. We can see that although Airbnb intensity tends to increase towards the city centre, as has been confirmed in previous studies (Dredge and Gyimóthy, 2015; Gutiérrez et al., 2017), the Airbnb phenomenon extends well beyond the central areas. We have examined the Airbnb distribution in all 4835 LSOAs and found that $82 \%$ of the areas (3982 LSOAs) have at least one active Airbnb listing. This also aligns with the findings by Coles et al. (2017) which suggest that although centrality is the main driver in Airbnb locations, Airbnb listings have become geographically more dispersed than many other comparable establishments such as hotels, guest houses and hostels. Figure 3a shows that more than $23 \%$ of available housing is being advertised through the platform. From the overall proportion, more than $16 \%$ of the dwellings are entire property listings that are being advertised as holiday rentals. The numbers for private and shared room proportions are lower than for entire property proportions at approximately $11 \%$ and $2 \%$, respectively.

Based on our previous criteria of possible misuse, Figure 3(b) and (c) show the geographical distribution of Airbnb properties that are being advertised for more than 180 days annually and are possible misused Airbnb properties. For comparison, these spatial representations are being visualised at two different scales: LSOA level and Borough level. The purpose of displaying two different spatial scales is to emphasise the point that when looking at a finer spatial scale, Airbnb is concentrated in some small geographical locations. Here, the possible implications of how they encroach on the availability of housing for permanent residents is more apparent. In 2018, approximately $0.25 \%$ (8200 properties) of the entire housing stock in London were advertised through the Airbnb platform for more than 180 days annually as entire property listings. Meanwhile, around $0.16 \%$ (5300 properties) of those are possible Airbnb misuses. When looking at the LSOA level as shown in Figure $3(\mathrm{~b})$, around $4 \%-7.5 \%$ of the housing stock of some LSOAs in Camden, Westminster, the City of London and Hackney contain entire property listings that are advertised for more than 180 days annually. A slightly lesser proportion, from 3.5\% to $7 \%$ of the housing stock in those LSOAs falls into the category of possible Airbnb misuse. Based on Figure 3(c), at the Borough level, up to $1.5 \%$ of the housing stock in the City of London can be categorised as 


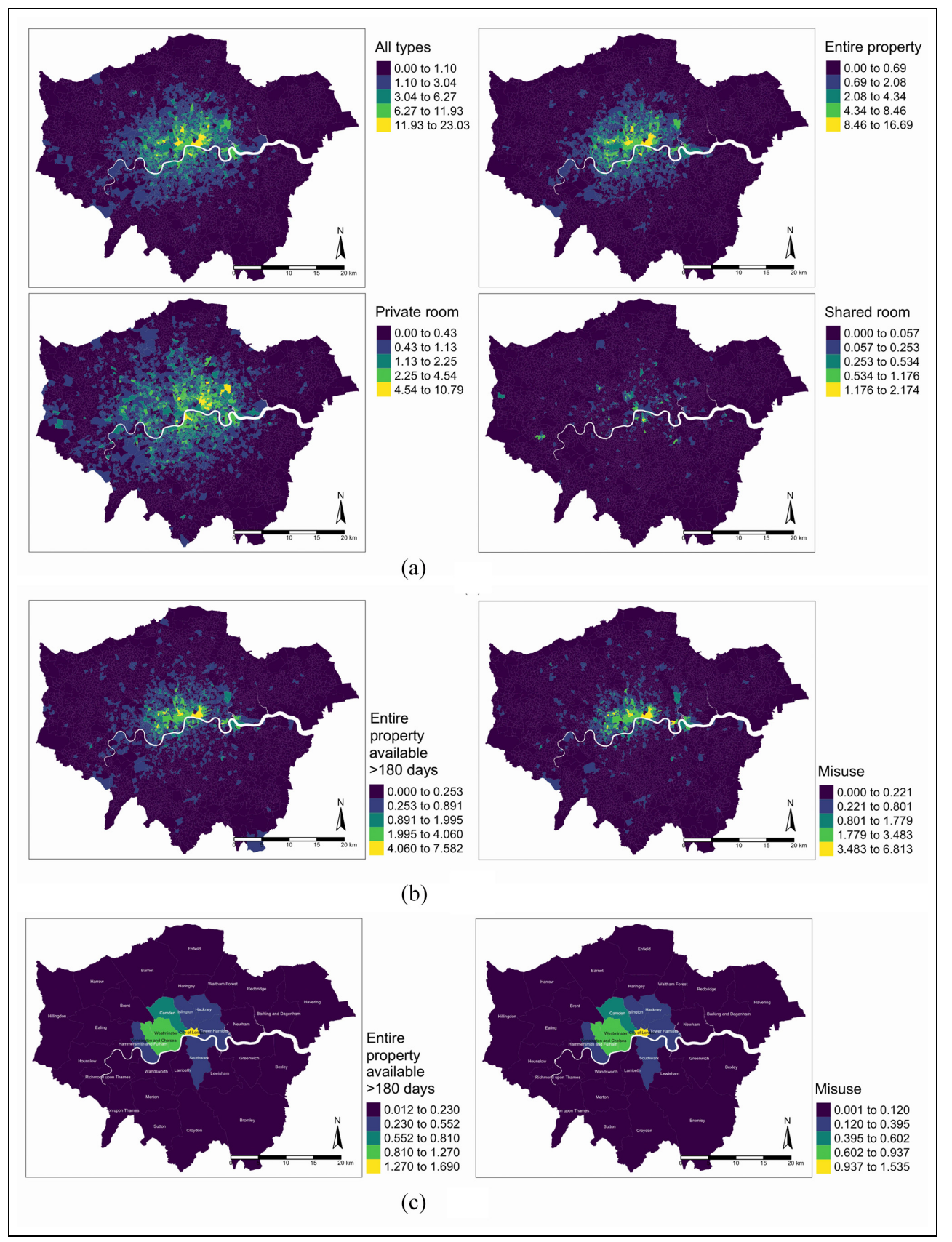

Figure 3. (a) Proportion of Airbnb according to room types, (b) proportion of possible Airbnb misuse at LSOA level, (c) proportion of possible Airbnb misuse at Borough level. Airbnb data are compared with the overall housing stock and shown as percentage values. 
possible Airbnb misuse. This is followed by up to $0.9 \%$ in Westminster and Kensington and Chelsea. This number is up to $0.4 \%$ of the housing stock in Tower Hamlets, Islington, Hackney and Southwark. These are the areas where house prices have soared and the problem of affordability is critical.

In New York City neighbourhoods, Coles et al. (2017) found that Airbnb is most profitable in middle-income neighbourhoods when compared with renting for permanent residents. Areas such as Tower Hamlets and Hackney are amongst those with the highest Airbnb supply and, according to Savills (2014), these two middle-income areas have been experiencing the highest influx of affluent newcomers and creative workers over recent years (Savills, 2014). So, there is an indication that the trend in New York might also be happening in London. Since 1998, prices in the east London borough of Hackney, have increased by $568 \%$, pushing the average cost of a flat above half a million pounds to $£ 515,600$, which is amongst the highest price increase in London during the last 20 years (Ivey, 2018). In their New York study, Wachsmuth and Weisler (2018) found that a significant Airbnb revenue stream appears in post-gentrified neighbourhoods, where the process of rent increases and displacements have happened already and neighbourhoods are transforming or have been transformed into wealthy areas. This seems to also be applicable to London in the wealthier areas in Central and West London and in those already gentrified in East and South London which are the primary areas for Airbnb.

\section{Possible Airbnb misuse and the relationship between housing characteristics based on the diversity of dwelling types and tenure}

In this section, we examine two housing characteristics, namely dwelling types and tenure and analyse their relationship with the distribution of Airbnb misuse. We employ Shannon's entropy to measure the spatial diversity of dwelling types in London. Entropy is a prominent measure which lets us study the complexity of cities in terms of their functional mix and heterogeneity (Batty et al., 2014; Wilson, 2013). It is a measure of variance, where the maximum is reached when the distribution of types is uniform or completely heterogeneous and the minimum when the distribution is peaked around a single type thus representing extreme homogeneity. Note that heterogeneity and homogeneity pertain to each unit of space (the LSOA) over which the distribution is measured in this context. The concept of entropy has been used in geography for different research purposes ranging from measuring urban land-use change and composition (Tan and $\mathrm{Wu}$, 2003; Zhao et al., 2004), to describing the geographic concentration of economic activity (Garrison and Paulson, 1973), as well as in urban spatial interaction modelling (Jat et al., 2008). In this article we use it in its statistical form as a measure of heterogeneity, employing Shannon's entropy, where information varies inversely with the probability of occurrence.

To construct this measure, let us define the probability $P_{i}$ of observing dwellings of type $i$ as follows:

$$
P_{i}=\frac{A_{i}}{\sum_{i}^{K} A_{i}}
$$

where $A_{i}$ and $K$ represent the number of dwelling types $i$ and the total number of observed dwelling types, respectively. Entropy denoted as $H$ is calculated as:

$$
H=-\sum_{i}^{K} P_{i} \ln P_{i}
$$

while its maximum $\left(H_{\max }\right)$ can be computed as: 


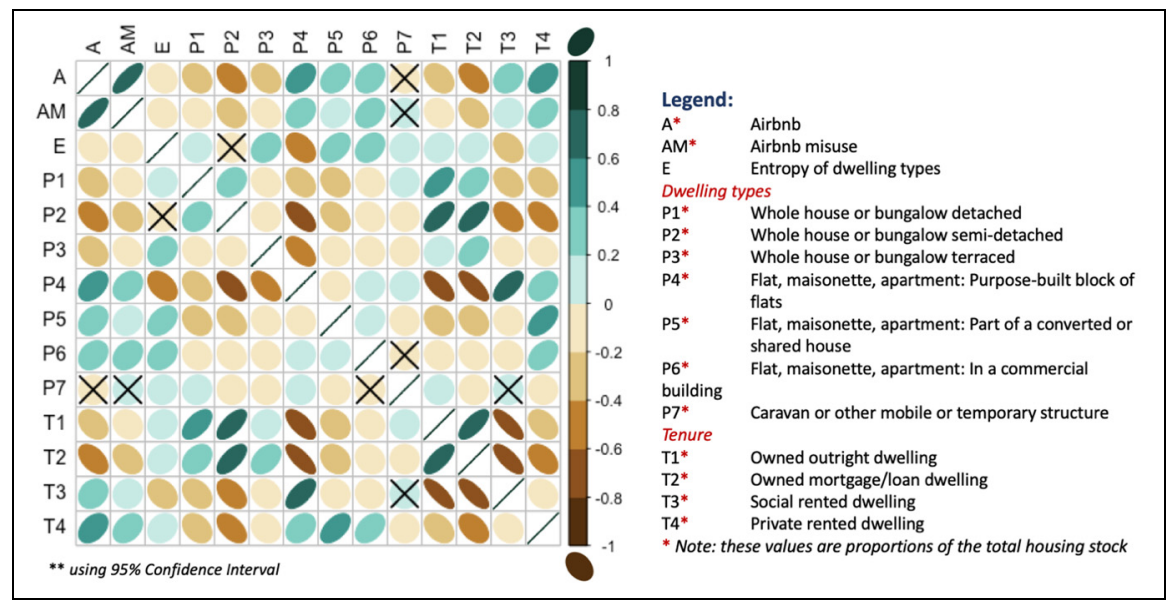

Figure 4. Correlations of Airbnb and dwelling types.

$$
H_{\max }=\ln K
$$

Entropy is thus a measure of heterogeneity with higher values indicating a higher number of dwelling types in an area (with more diversity or a greater mix). Using the data, we calculate the entropy for the distribution of dwelling types in each of London's LSOAs using equations (1) and (2). Maximum entropy, defined using equation (3), is achieved when all types are equally likely, thus presenting maximum diversity (Atkinson et al., 2014). The maximum value for our case is approximately 1.94 (indicating that there are seven dwelling types $(\ln 7)$ present in that area with an equal proportion in each) while the minimum entropy is 0 (indicating an area dominated by a single dwelling type).

Figure 4 shows the correlation matrix $[r]$ between the proportion of Airbnb misuse, with the various dwelling types as well as their entropy measures calculated previously and the type of homeownership in London (owned or rented). Through this analysis, we expand the work of Quattrone et al. (2016) who found that Airbnb offerings correlate with various socio-economic attributes of their geographical locations. The result shows that the proportion of Airbnb misuse is positively correlated with the proportion of specific dwelling types including purposebuilt flats/apartments and flats in commercial buildings $(r=+0.28$ and +0.27 , respectively) and areas that have a higher proportion of private rented properties $(r=+0.33)$. In contrast, the proportion of Airbnb misuse is negatively correlated with the entropy of the dwelling type, detached houses, semi-detached houses and owned properties $(r=-0.14,-0.25,-0.20$ and -0.31 , respectively).

The variables can be visualised in the map of Figure 5. Figure 5(a) shows the entropy of dwelling types where the darker colour indicates higher entropy values, meaning that those areas have a greater diversity of dwelling types. The entropy measure negatively correlates with Airbnb misuse and from Figure 5(a) we can see that the core of inner London Boroughs seems very homogeneous (with low entropy ranging from 0.05 to 0.62), where heterogeneity filters out towards the periphery of the city. The outer London Boroughs are thus dominated by diverse dwelling types (with mid to high entropy 


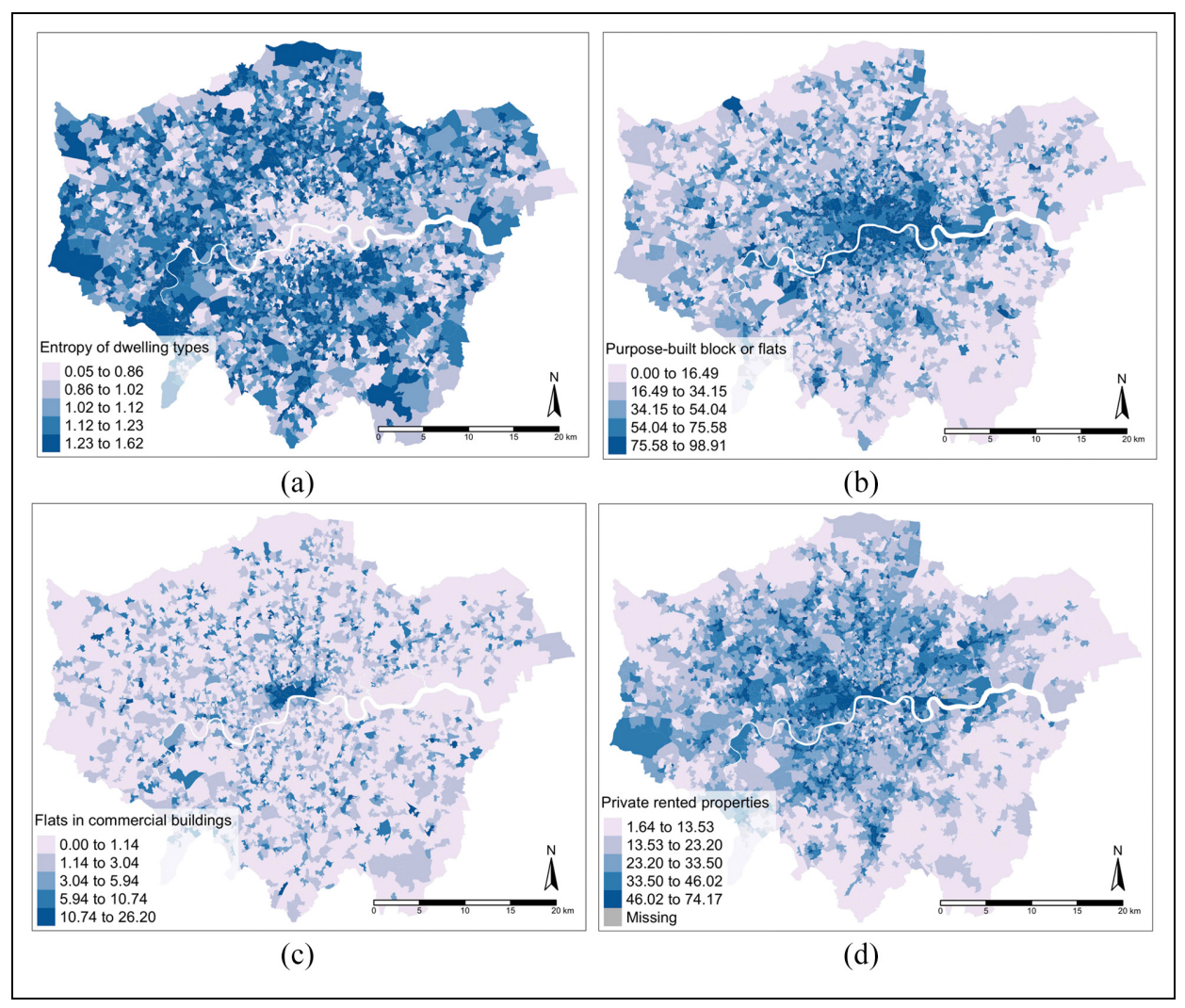

Figure 5. The spatial distribution of the diversity of dwelling types, proportion of purpose-built block of flats, flats in commercial buildings and privately rented properties. The sub-captions show the correlation coefficients $r$ with respect to the proportions of Airbnb misuse. (a) Entropy of dwelling types, the darker colours indicate high diversity of dwelling types: negatively correlated with Airbnb misuse, correlation coefficient $r$ of -0.14 . (b) Proportion of purpose-built block or flats in London: positively correlated with Airbnb misuse, correlation coefficient $r$ of +0.28 . (c) Proportion of flats in commercial buildings in London: positively correlated with Airbnb misuse, correlation coefficient $r$ of +0.27 . (d) Proportion of private rented properties in London: positively correlated with Airbnb misuse, correlation coefficient $r$ of +0.33 .

values). Past research tends to associate the diversity of the city with its land-use mix, but this is very different from the picture we have presented in this article. We focus on the diversity of dwelling types. This finding can be linked to the history of housing in London with its concentration of purposebuilt flats dominating the Central and Eastern areas from the 1980s onward. This results in low diversity (low entropy) in areas such as the City (of London), Hackney, Tower Hamlets and parts of Kensington and Lambeth, as well as a fraction of housing in Westminster. These low entropy areas happen to be prime locations for Airbnb misuse.

Figure 5(b) shows the distribution of purpose-built blocks of flats (flats that have been constructed originally as flats, as opposed to conversions from other functions). Airbnb misuse shows a positive 
correlation with purpose-built flat dwellings indicated by an $r$ of +0.28 . Although spatially distributed throughout London, the highest proportion of purpose-built flats is 99\%, mostly in Tower Hamlets, the City of London and Hackney and there is a high proportion of flats generally distributed throughout Central London towards East London with some increase in proportion in Greenwich. These overlap with the areas with the highest concentration of Airbnb misuse. Figure 5(c) shows the distribution of flats in commercial buildings. The proportion of this type of dwelling is generally lower compared with other types of flats (the highest is $26 \%$ of the overall dwellings, located in an LSOA in Westminster), and they are dispersed all around London. Overall, the $r$ coefficient shows a positive linear correlation between Airbnb misuse and most flat types, both purpose-built and in commercial buildings.

Figure 5(d) shows that Airbnb misuse has a positive correlation $(r=+0.33)$ with areas that have a higher proportion of private rented properties. In London, private renting was once the largest tenure until the 1980 s, when there was a dramatic transformation to ownership. Almost $40 \%$ of households in inner London either owned or were buying their own homes at the time (Hamnett, 2004). Recently, the number of private rentals has rapidly risen to $26 \%$, making it the second-largest tenure, while owner occupancy has fallen in commensurate terms (GLA, 2015). The median price of the private rented sector varies hugely between various boroughs, where higher rents tend to be located in inner London boroughs (areas with the large rented sector) (GLA, 2015). Many Londoners have been priced out and have been moving to the commuter belt areas because of the more than proportionate annual increase of rent in inner and central London (Fraser, 2017). The problem of affordability is even worse in the prime London LSOAs, where Airbnb is heavily concentrated, as in areas with mid to high rental prices. In August 2018, there was a $24 \%$ drop in available properties to rent in Greater London compared with the previous year and thus an increase in rent in the future is likely (Silva, 2018). It is possible (although not conclusive) that Airbnb might be exacerbating this problem.

\section{Modelling rental changes in London Boroughs and their Airbnb misuse associations}

To complete the analysis, we model various factors that might have close associations with rental price changes in London Boroughs, through a linear model fitted using multiple regression analysis. This method allows us to examine the linearity of the relationships using multiple variables or covariates within the same model. As we focus on the price index of an area rather than on individual dwellings, we move away from LSOA to Borough scale. Thus, the rental price changes are based on individual Zoopla property data aggregated to Borough level from 2015 to 2017. Figure 6(a) shows the year-to-year variations of rent prices in each London Borough based on the analysis of 1.3 million sample asking rental price data (2010-2017). More variations can be found in areas where rent prices are higher than the rest of London, such as Kensington and Chelsea, Westminster and City of London. This is possibly due to two causes: the nature of the area and the nature of the data. First, these areas have some prime properties with very high prices that might distort the data. Any sudden spike (or drop) in prices for these properties might bring up (or bring down) the overall mean prices. Second, the property asking prices in Zoopla are used as samples in determining the rent, and these samples are geographically uneven. However, even with these 


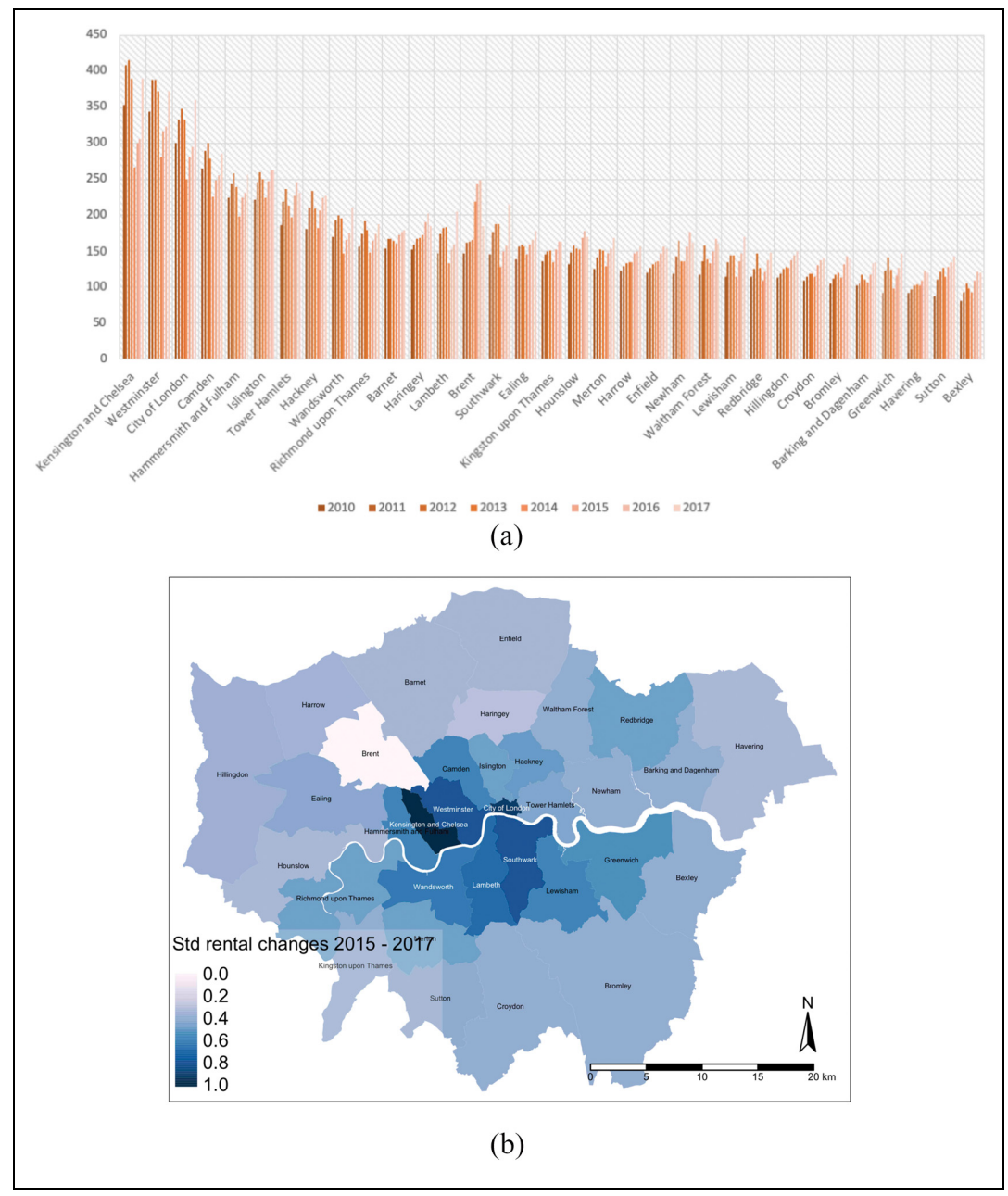

Figure 6. Asking rental price in London Boroughs. (a) Year-to-year variations of rental price per-bedroom per-week in London Boroughs. (b) Standardised rental changes in 2015-2017.

limitations, our data provide an adequate snapshot of the nature of the rental price market in London.

Figure 6(b) shows the spatial distribution at the coarser spatial scale for 32 Boroughs and the City of London. The trend shows an overall cumulative increase in all London Boroughs from 2015 to 2017 . We use standardised rental change values after applying the min-max normalisation method (Jayalakshmi and Santhakumaran, 2011). The highest rental changes occur generally in areas in central London and south of the River Thames, especially in Lambeth, Southwark, Hammersmith and Fulham, Wandsworth, Camden, City of London, Westminster as well as Kensington and Chelsea where rent changes in the range of $20 \%-43 \%$ have occurred. To validate this finding, we compare the rent increase with the previous study by GMB London, a British Trade Union, that compares the rent increase with the rise in wages. The study shows that the overall rental price for a two- 
bedroom flat in London has increased by $21.7 \%$ between 2011 and 2018, while monthly earnings have increased by $9.1 \%$ (GMB London Region, 2019). The largest gap between rents and pay-rises occurs in Greenwich where rent prices have increased by $50 \%$ with only $7.2 \%$ change in monthly earnings (GMB London Region, 2019). This is followed by Lewisham, Newham, Barking and Dagenham, Waltham Forest and Croydon with more than $40 \%$ change in rent (GMB London Region, 2019). The report similarly suggests rapid rent increases, especially in South London.

We have discussed previously that the high rental and house prices in London are a product of complex and multifaceted issues. Thus, to simplify this, several important variables are examined. Let us denote by $\Delta$ Rent $_{2015-2017}$, the change in rental prices from 2015 to 2017 . Linearly relating it to a set of explanatory variables through the parameters $\beta_{1}, \beta_{2}, \beta_{3}$ and $\beta_{4}$, the regression function takes the following form:

\section{$\Delta$ Rent $_{2015-2017}=\beta_{1}$ Misuse $_{2015}$ \\ $+\beta_{2}$ Add.housing $2015-2016$ \\ $+\beta_{3}$ Dist.to.centre \\ $+\beta_{4}$ Prop.owned.rented 2015}

where $\Delta$ Rent $_{2015-2017}$ is the rental price changes in 2015-2017 based on aggregated Zoopla asking rental price data; Misuse $_{2015}$ is the numbers of Airbnb misuse in 2015; Add.housing $2015-2016$ is the net additional housing in 2015-2016 including, but not limited to, new housing constructions, conversions and demolitions; Dist.to.centre is the Euclidean distance from each borough to the city centre (from City of London); and last, Prop.owned.rented 2015 is the proportion of owned housing (outright and via a mortgage) compared with the proportion of rented housing (both from private landlords or local authority) in 2015. We have discussed how these variables might affect rental price changes, as we have previously examined the presence of Airbnb misuse. The descriptive statistics of these variables are presented in Table 1.

To ensure the validity of our multiple regression results, we compute the variance inflation factor (VIF) and examine whether multicollinearity exists within our variables, indicated by a VIF score above 5 (Wheeler, 2007; Wheeler and Tiefelsdorf, 2005). Table 1 shows low VIF values, thus multicollinearity is not a problem in our data set. Furthermore, to examine the normality of our data distribution for each variable, we apply the Shapiro-Wilk test (Shapiro and Francia, 1972). The statistical test shows a significant departure from normality for variables Misuse $2015_{25}$ and Prop.owned. rented $_{2015}$. Thus, log transformations are used to these two variables as it is recommended for obtaining normal distribution in a skewed data set. After these transformations, a simple linear regression using multiple variables is deemed suitable to model our data.

We apply multiple regression to model the relationship between the rental price changes in 2015-2017 and the explanatory variables. The result is presented in Table 2 . The model can explain more than $50 \%$ of the variance indicated by $R^{2}$ of 0.62 and an Adjusted $R^{2}$ of 0.56 . We found that under the 0.05 significance level (or 95\% confidence interval), there are statistical relationships between our response variable, rental price changes in 2015-2017 and two of our explanatory variables: the numbers of Airbnb misuse in 2015 and proportion of owned compared with rented properties. Figure 7 is a partial regression plot that shows the true relationship between a response and each of the explanatory variables in a multiple regression by also controlling other explanatory variables. It displays the linear relationship by regressing: (1) the residuals from regressing the response 
Table I. Descriptive statistics and VIF values for the response and explanatory variables

\begin{tabular}{lclll}
\hline Variables $(n=33)$ & Mean & Std dev. & Shapiro-Wilk (sig.) & VIF \\
\hline Rent $_{2015-2017}$ & 0.473 & 0.194 & 0.072 & 2.668 \\
Misuse $_{2015}$ & 0.110 & 0.196 & $0.000^{* * *}$ & 3.287 \\
Add.housing $_{2015-2016}$ & 0.845 & 0.486 & 0.351 & 1.255 \\
Dist.to.centre $_{\text {Prop.owned.rented }} 015$ & 12.309 & 6.214 & 0.461 & 3.536 \\
\hline
\end{tabular}

Note: $* * *$ indicates significance at the $99 \%$ level.

Table 2. Multiple regression result for rental price changes in London Boroughs.

\begin{tabular}{|c|c|c|c|c|c|}
\hline Variables & Coefficient $(\beta)$ & Std error & $t$ & $p$-value & $95 \% \mathrm{Cl}^{*}$ \\
\hline Intercept & $0.9113 * * *$ & 0.094 & 9.709 & 0.000 & 0.719 to 1.104 \\
\hline Misuse $_{2015}$ & $0.0838 * * *$ & 0.022 & 3.808 & 0.001 & 0.039 to 0.129 \\
\hline Add.housing $2015-2016$ & -0.0095 & 0.052 & -0.184 & 0.856 & -0.115 to 0.096 \\
\hline Dist.to.centre & $-0.007 \mid$ & 0.008 & -0.874 & 0.390 & -0.024 to 0.009 \\
\hline Prop.owned.rented 2015 & $0.1623 * * *$ & 0.063 & 2.595 & 0.015 & 0.034 to 0.290 \\
\hline
\end{tabular}

Note: $95 \% \mathrm{Cl}$ : $95 \%$ confidence interval.

Source: $* * *, * * *$ indicates significance at the $90 \%, 95 \%$ and $99 \%$ level, respectively.

variable denoted as $Y$ against all explanatory variables except the selected one denoted as $X_{[j]}$; against (2) the residuals from regressing $X_{[j]}$ with the remaining independent variables (Velleman and Welsch, 1981). It shows that Airbnb misuse in 2015 and the proportion of owned properties are positive predictors of rental price changes. For every $100 \%$ increase of Airbnb misuse in the previous two years, the estimated mean rental price increase is approximately 0.08 unit. This is equivalent to $8 \%$ unit rental price-per-week increase within the two-year time frame. If we use the mean rental price changes, this association is equivalent to a $£ 90$ difference in rents annually. Moreover, based on our model, every $100 \%$ increase in the proportion of owned versus rented properties would be associated with a rental price increase of about $16 \%$. Thus, doubling the proportion of owned properties can be associated with an annual rental price increase of approximately $£ 180$. The remaining variables, net additional housing in 2015-2016 and distance to the city centre, are not significant explanatory variables for the changes in the rental price in our case study.

As with most statistical tests, the validity of our multiple regression analysis depends on whether our data have met the underlying regression assumptions. There are four assumptions for this linear model: variable independence, linearity, normality and homoscedasticity. Violations of these assumptions could lead to bias in the results. We conduct a series of residual analysis, as a well-fitted multiple regression would adhere to the assumptions mentioned previously. The Jarque-Bera test for normality of the distribution (Jarque and Bera, 1987) shows that the residuals come from a normal 


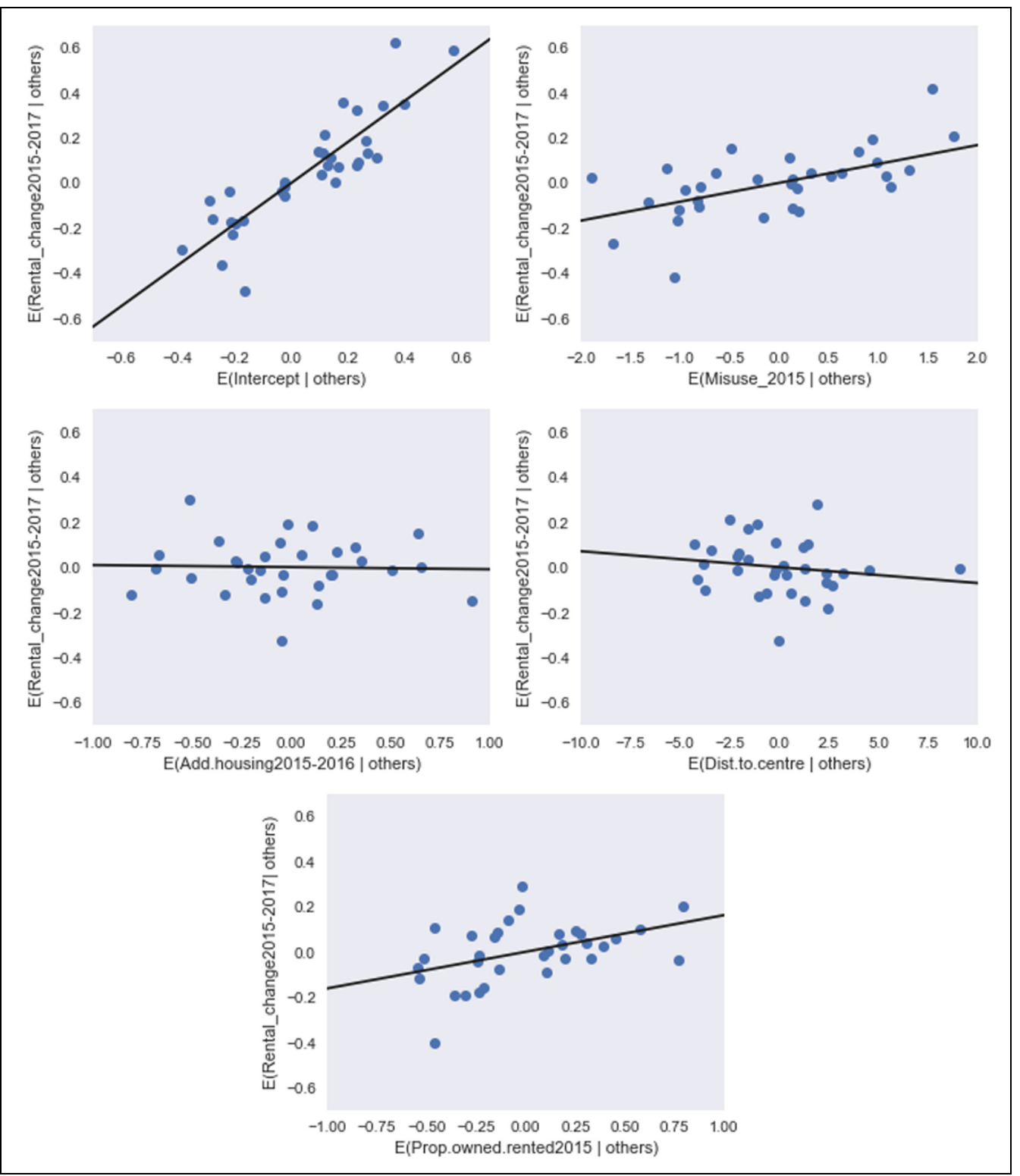

Figure 7. The partial regression plots show the relationships when the variables are modelled together, indicating both positive and negative relationships. The plot shows linear relationship by regressing: $(I)$ the residuals from regressing the response variable $\left(\Delta R_{\text {ent }}\right.$ 2015-2017) $)$ against all explanatory variables except the selected one denoted as $X_{[j]}$; against (2) the residuals from regressing $X_{[j]}$ with the remaining independent variables. $X_{[j]}$ are Intercept, Misuse 2015 , Add.housing $2015-2016$, Dist.to.centre and Prop.owned.rented 2015 , respectively. 
distribution, indicated by the $p$-value of 0.8 ( $>0.05$ significance level). We use BreuschPagan-Godrey test to account for the homoscedasticity of the errors assumption (Breusch and Pagan, 1979). We found evidence to accept the null hypothesis that there is no serial correlation of the error indicated by the $p$-value of $0.41(>0.05$ significance level). Our residuals diagnostic shows that our model has met all these regression assumptions.

\section{Discussion and conclusion}

The concept of peer-to-peer renting through the emerging online platform economy, such as that developed by Airbnb, has various implications for long-term housing supply. One of the possible implications is the risk of conversion from permanent private rented housing to short-term holiday rentals (Barron et al., 2018), creating a critical problem in a city where the housing market is as overheated and as complex as in London. However, the complexity of the housing system in London makes it very challenging to pinpoint the precise causes of several entangled problems that pervade the housing market. London is facing an extreme problem of unaffordability, supply scarcity and growing numbers of 'generation rent', especially for the younger adult cohorts. The presence of Airbnb in the last decade has stimulated concern that its growing usage is feared to have exacerbated the uncontrollable growth of rental prices by constraining the housing supply even further. As such, this study provides the first comprehensive set of measures that analyse the relationship between possible Airbnb misuse and the overall housing characteristics in London.

Based on our analysis, Airbnb misuse is located mainly in areas with low dwellingtype diversity, dominated by flats and apartments. Moreover, Airbnb misuse is associated with a high proportion of private rented properties. As previously discussed in the body of this article, the renting population is at the highest risk of being stuck in the precarious rental market. The assured shorthold tenancy (AST) makes them less protected in this tenure as it gives the right to landlords to (1) evict tenants with just two months notice; and (2) increase rents arbitrarily (Judge and Tomlinson, 2018). With the exponential growth of Airbnb, landlords now have the choice to advertise their properties for permanent residence or to convert their properties to short-term holiday rentals.

Considering the association between possible Airbnb misuse with rental price changes, it is plausible that our speculation that Airbnb disrupts the provision of housing for permanent residents is wellgrounded. More than 2\% of the total housing stock has been advertised via the Airbnb platform in 2018. Any resulting impact can be especially significant in such areas where the possible misuse of Airbnb properties (especially entire property listings where hosts have multiple listings) take a significant portion of the overall housing stock. At the LSOA level, up to $23 \%$ of the properties are advertised in the Airbnb platform in 2018. Up to $7 \%$ of these dwellings are potential misuse of Airbnbs that are available for more than 180 days, and for which hosts have multi-listings. This misuse with multi-listings comprises almost $0.15 \%$ of the overall housing stock, equivalent to approximately 5300 properties that turn into shortterm rentals. Thus, an emphasis should be placed on protecting the supply of rental properties. Considering how fast Airbnb has grown, and given the deregulation and the low level of regulation enforcement encouraging more people to participate (Ferreri and Sanyal, 2018), it would appear that more proper and legitimate use of Airbnb should be enforced accordingly.

Aligned with other scholarly findings such as those by Lee (2016), Horn and 
Merante (2017) and Schäfer and Braun (2016), we find evidence that Airbnb might be associated with the rising rental price changes in London. Also, our result is comparable with previous research quantifying the possible effect Airbnb has on the housing market. Horn and Merante (2017) found an association of one standard deviation in Airbnb listings with $0.4 \%$ increase in asking price, this value is up to $3.1 \%$ in census tracts with a high density of Airbnb in Boston. In the USA, Barron et al. (2018) argue that $1 \%$ increase of Airbnb listings in a median owner-occupancy zipcode leads to $0.018 \%$ increase in rents. Garcia-López et al. (2019) found that in Barcelona, there is an estimated increase in rents up to $7 \%$ in areas with high Airbnb activity. Sheppard and Udell (2018) analyse the impact of Airbnb on the property market and found an increase in property values from $6 \%$ to $9 \%$ when doubling the Airbnb listings within $300 \mathrm{~m}$ of a property. To our knowledge, our study is the first to model the association between rental price, and specifically Airbnb misuse, as opposed to overall Airbnb activities. Thus it focuses on quantifying the possible impacts resulting from the violation of short-term rentals. In cities such as London, where the private rented sector plays a huge role in the housing market (Chu, 2018; Future of London, 2017), it is important to investigate this relationship.

This article advances knowledge towards understanding the effects of Airbnb on housing and contributes to the effort of other academics in this direction, such as Horn and Merante (2017), Jefferson-Jones (2014), Lee (2016), Quattrone et al. (2016), Schäfer and Braun (2016) and Wachsmuth and Weisler (2018) to name a few. Nevertheless, more perspectives from different cities are still needed. It is important to conduct such critical analyses to overcome the challenges that arise from rapid developments of new phenomena such as those resulting from the platform economy.
Regulations need to be carefully considered in order not to stifle innovation. Platforms such as Airbnb are a key representation of the wider platform economy, encompassing mobility, retailing and capital investment such as housing. Finding the right balance between regulation and allowing innovation to thrive can only occur when these processes are better understood.

\section{Declaration of conflicting interests}

The author(s) declared no potential conflicts of interest with respect to the research, authorship and/or publication of this article.

\section{Funding}

The author(s) received no financial support for the research, authorship and/or publication of this article.

\section{ORCID iDs}

Zahratu Shabrina (iD https://orcid.org/0000-00018246-8229

Michael Batty (iD https://orcid.org/0000-00029931-1305

\section{Note}

1. Based on Visit Britain UK Occupancy Survey for hotels, guest houses and bed and breakfast establishments in the UK, the occupancy rates for years 2017-2019 for rooms are $69 \%-79 \%$, while bed-space occupancy ranges from $53 \%$ to $55 \%$. Therefore, this study chose the lower limit of the occupancy rates and assumes that Airbnb listings are being booked with an average $50 \%$ occupancy rate. Given the uncertainty in the exact number, where probable under- or over-representation might occur, we use the term 'potential/possible' misuse. For more info regarding the survey, see https://www.visitbritain.org.

\section{References}

Atkinson P, Zhang J and Goodchild MF (2014) Scale in Spatial Information and Analysis. Boca Raton, FL: CRC Press. 
Barron K, Kung E and Proserpio D (2018) The sharing economy and housing affordability: Evidence from Airbnb. SSRN. Available at: https://papers.ssrn.com/sol3/ papers.cfm?abstract_id $=3006832$

Batty M, Morphet R, Masucci P et al. (2014) Entropy, complexity, and spatial information. Journal of Geographical Systems 16(4): 363-385.

Bentham M (2019) Affordability ratio: London first-time buyers spend 13 times earnings for first home, according to latest figures. Available at: https://www.homesandproperty.co.uk/ property-news/london-firsttime-buyers-spend13-times-earnings-for-first-home-according-tolatest-figures-a 122606.html

Beswick J, Alexandri G, Byrne M, et al. (2016) Speculating on London's housing future: The rise of global corporate landlords in 'post-crisis' urban landscapes. City 20(2): 321-341.

Breusch TS and Pagan AR (1979) A simple test for heteroscedasticity and random coefficient variation. Econometrica: Journal of the Econometric Society 46: 1287-1294.

Buck N, Gordon I, Hall P, et al. (2013) Working Capital: Life and Labour in Contemporary London. London: Routledge.

Chu B (2018) Millennials are set to rent for the rest of their lives - And if they do, the UK's economy will see serious consequences. Available at: https://www.independent.co.uk/ voices/millennials-renting-life-uk-economyconsequences-housing-market-prices-germanya8308776.html

Coles PA, Egesdal M, Ellen IG, et al. (2017) Airbnb usage across New York City neighborhoods: Geographic patterns and regulatory implications. In: Cambridge Handbook on the Law of the Sharing Economy. Forthcoming. Available at: https://papers.ssrn.com/sol3/ papers.cfm?abstract_id=3048397, pp. 1-26.

Collinson P (2017) One in seven UK private tenants pays more than half income in rent Study. Available at: https://www.theguardian. com/money/2017/jul/03/one-in-seven-privatetenants-pays-more-than-half-income-in-rentstudy-finds

Colson T (2017) 10 years on: How the global financial crisis transformed the UK housing market and priced out millennials. Available at: https://www.businessinsider.com/how-2007- financial-crisis-transformed-uk-housing-market2017-7? $\mathrm{r}=\mathrm{US} \& \mathrm{IR}=\mathrm{T}$

Davidson M and Wyly E (2012) Class-ifying London: Questioning social division and space claims in the post-industrial metropolis. City 16(4): 395-421.

Dorling D (2014) All That Is Solid: The Great Housing Disaster. London: Penguin Books.

Dredge D and Gyimóthy S (2015) The collaborative economy and tourism: Critical perspectives, questionable claims and silenced voices. Tourism Recreation Research 40(3): 286-302.

Edwards M (2016) The housing crisis and London. City 20(2): 222-237.

Elliott L (2018) London house prices fall at fastest rate in 10 years. Available at: https://www.theg uardian.com/money/2019/jul/17/london-houseprices-fall-at-fastest-rate-in-10-years-ons

Ferreri M and Sanyal R (2018) Platform economies and urban planning: Airbnb and regulated deregulation in London. Urban Studies 55(15): 3353-3368.

Foster D (2015) Right to buy: A history of Margaret Thatcher's controversial policy. Available at: https://www.theguardian.com/housingnetwork/2015/dec/07/housing-right-to-buy-mar garet-thatcher-data

Fraser I (2017) Record numbers of renters have left London over the past year - And this is where they're going. Available at: https:// www.telegraph.co.uk/property/renting/recordnumbers-renters-have-left-london-past-yeargoing/

FTI Consulting LLP (2012) Understanding supply constraints in the housing market: A study on understanding supply constraints in the housing market. London. Available at: https://england.shelter.org.uk/_data/assets/pdf_file/0006/ 576906/120716_Understanding_Supply_Constr aints_in_the_Housing_Market.pdf

Future of London (2017) Engaging London's private rented sector. Available at: https://www. futureoflondon.org.uk/wp-content/uploads/deli ghtful-downloads/2017/12/FoL-Engaging-Londons-PRS-WEB.pdf

Gallent N, Durrant D and May N (2017) Housing supply, investment demand and money creation: A comment on the drivers of London's housing crisis. Urban Studies 54(10): 2204-2216. 
Garcia-López MA, Jofre-Monseny J, Martínez $\mathrm{R}$, et al. (2019) Do short-term rent platforms affect housing markets? Evidence from Airbnb in Barcelona. IEB Working Paper 2019/05, Institut d'Economia de Barcelona.

Garrison CB and Paulson AS (1973) An entropy measure of the geographic concentration of economic activity. Economic Geography 49(4): 319-324.

GLA Intelligence Greater London Authority (2015) Population growth in London, 19392015. Available at: https://www.redbridge.gov. uk/media/3603/ced112-gla-population-growthin-london-1939-2015.pdf

GMB London Region (2019) Rent in London up $25.9 \%$ since 2011 compared to $9.1 \%$ pay rises. Available at: https://www.gmblondon.org.uk/ news/rent-and-earnings-in-london

Greater London Authority (GLA) (2015) The evidence base for the Mayor's housing strategy. Technical report, Greater London Authority, London. Available at: www.london.gov.uk

Gutiérrez J, García-Palomares JC, Romanillos G, et al. (2017) The eruption of Airbnb in tourist cities: Comparing spatial patterns of hotels and peer-to-peer accommodation in Barcelona. Tourism Management 62: 278-291.

Guttentag DA and Smith SL (2017) Assessing Airbnb as a disruptive innovation relative to hotels: Substitution and comparative performance expectations. International Journal of Hospitality Management 64: 1-10.

Hamnett C (2004) Unequal City: London in the Global Arena. London: Routledge.

Hilber CA (2015) UK Housing and Planning Policies: The Evidence from Economic Research. London: Centre for Economic Performance, The London School of Economics.

HM Government United Kingdom (2015a) Deregulation act section 44. Available at: http://www.legislation.gov.uk/ukpga/2015/20/ section/44/enacted

HM Government United Kingdom (2015b) Deregulation act commentary on section 44/ 45. Available at: http://www.legislation.gov.uk/ukpga/2015/20/notes/division/5/46

Holman N, Fernández Arrigoitia M, Scanlon K, et al. (2015) Housing in London: Addressing the Supply Crisis. London: The London School of Economics and Political Science.
Horn K and Merante M (2017) Is home sharing driving up rents? Evidence from Airbnb in Boston. Journal of Housing Economics 38: 14-24.

Ikkala T and Lampinen A (2015) Monetizing network hospitality: Hospitality and sociability in the context of Airbnb. In: Proceedings of the 18th ACM conference on computer supported cooperative work \& social computing. New York: ACM. Available at: https://doi.org/ 10.1145/2675133.2675274, pp. 1033-1044.

Ivey P (2018) Top borough: Hackney house prices see highest 20-year rise in UK, boosted by tech sector and new homes. Available at: https:// www.homesandproperty.co.uk/property-news

Jarque CM and Bera AK (1987) A test for normality of observations and regression residuals. International Statistical Review/Revue Internationale de Statistique 55(2): 163-172.

Jat MK, Garg PK and Khare D (2008) Monitoring and modelling of urban sprawl using remote sensing and GIS techniques. International Journal of Applied Earth Observation and Geoinformation 10(1): 26-43.

Jayalakshmi T and Santhakumaran A (2011) Statistical normalization and back propagation for classification. International Journal of Computer Theory and Engineering 3(1): 1793-8201.

Jefferson-Jones J (2014) Airbnb and the housing segment of the modern sharing economy: Are short-term rental restrictions an unconstitutional taking. Hastings Const. LQ 42: 557.

Jones CL (2019) Help to buy is finally being scrapped. Here's why it was a terrible idea. Available at: https://www.citymetric.com/politics/help-buy-finally-being-scrapped-here-s-whyit-was-terrible-idea-4419

Judge L and Tomlinson D (2018) Home improvements: Action to address the housing challenges faced by young people. Resolution Foundation. Available at: https://www.resolution foundation.org/app/uploads/2018/04/Homeimprovements.pdf.

Kay J (2017) How to solve the UK housing crisis. Available at: https://www.ft.com/content/ d8854b1e-bf08-11e7-823b-ed31693349d3

Kemp PA (2015) Private renting after the global financial crisis. Housing Studies 30(4): 601-620.

Lee D (2016) How Airbnb short-term rentals exacerbate Los Angeles's affordable housing 
crisis: Analysis and policy recommendations. Harvard Law \& Policy Review 10: 229.

Li J, Moreno A and Zhang DJ (2016) Pros vs joes: Agent pricing behavior in the sharing economy. Working Paper No. 1298, Michigan Ross School of Business, Harvard University.

Lima V (2019) Towards an understanding of the regional impact of Airbnb in Ireland. Regional Studies, Regional Science 6(1): 78-91.

McAfee A and Brynjolfsson E (2017) Machine, Platform, Crowd: Harnessing Our Digital Future. New York: WW Norton \& Company, Inc.

Macfarlane L (2017) It's time to call the housing crisis what it really is: The largest transfer of wealth in living memory. Available at: https:// neweconomics.opendemocracy.net/time-call-hou sing-crisis-really-largest-transfer-wealth-livingmemory/

Mayor of London (2015) Housing in London 2015 - The evidence base for the Mayor's housing strategy. Greater London Authority. Available at: https://data.london.gov.uk/dataset/housing-london

Mayor of London (2018) The draft new London plan. Greater London Authority. Available at: https://www.london.gov.uk/what-we-do/planning/london-plan/new-london-plan/draft-newlondon-plan/

Morrison C (2018) How the global financial crisis hit the UK housing market. Available at: https://www.independent.co.uk/news/business/ analysis-and-features/global-financial-crisis-lehman-brothers-property-house-prices-uk-housing-market-a8538176.html

Murie A (2015) The Right to Buy: History and Prospect. History and Policy, KCL and University of Cambridge. Available at: http:// www.historyandpolicy.org/policy-papers/ papers/the-right-to-buy-history-and-prospect

Parker GG, Van Alstyne MW and Choudray SP (2016) Platform Revolution: How Networked Markets Are Transforming the Economy? And How to Make Them Work for You. New York: WW Norton \& Company, Inc.

Quattrone G, Proserpio D, Quercia D, et al. (2016) Who benefits from the 'sharing' economy of Airbnb? In: Proceedings of the 25th International Conference on World Wide Web, pp. 1385-1394. Republic and Canton of Geneva, Switzerland:
International World Wide Web Conferences Steering Committee. Available at: https:// doi.org/10.1145/2872427.2874815.

Savills (2014) Gentrification of London. Available at: https://www.savills.co.uk/research_articles/229130/171784-0

Schäfer P and Braun N (2016) Misuse through short-term rentals on the Berlin housing market. International Journal of Housing Markets and Analysis 9(2): 287-311.

Shapiro SS and Francia RS (1972) An approximate analysis of variance test for normality. Journal of the American Statistical Association 67(337): 215-216.

Sheppard S and Udell A (2018) Do Airbnb properties affect house prices? Williams University Working Paper. Available at: https://pdfs.semanticscholar.org/c41a/555192f8b8a63413cfd 461f4295b95123e6f.pdf?.ga $=2.259932618$. 15608359.1596668421-1815735046.1596668421

Silva M (2018) London rents rising amid shortage of properties. Available at: https://www.land lordtoday.co.uk/breaking-news/2018/9/sharpfall-in-the-number-of-homes-to-let-in-london

Slater T (2016) Free market think tanks and the production of ignorance. In: Springer S, Birch K and Macleavey J (eds) Handbook of Neoliberalism. Abingdon: Routledge, pp. 370-383.

Snelling C, Colebrook C and Murphy L (2016) Homesharing \& London's Housing Market. London: Institute for Public Policy Research.

Stone B (2017) The Upstarts: Uber, Airbnb, and the Battle for the New Silicon Valley. London: Penguin Books.

Tan Y-Z and Wu C-F (2003) The laws of the information entropy values of land use composition. Journal of Natural Resources 18(1): 112-117.

Trust for London (2017) London's poverty profile data. Available at: https://www.trustforlondon.org.uk/data/topics/housing/

Velleman P and Welsch R (1981) Efficient computing of regression diagnostics. The American Statistician 35(4): 234-242.

Volgger M, Pforr C, Stawinoga AE, et al. (2018) Who adopts the Airbnb innovation? An analysis of international visitors to Western Australia. Tourism Recreation Research 43(3): 305-320. 
Wachsmuth D and Weisler A (2018) Airbnb and the rent gap: Gentrification through the sharing economy. Environment and Planning A: Economy and Space 50(6): 1147-1170.

Walker PJ (2017) 'Bank of mum and dad' making housing market more unfair, study finds. Available at: https://www.theguardian.com/ society/2017/mar/27/bank-of-mum-and-dadhousing-market-unfair-study

Watt P and Minton A (2016) London's housing crisis and its activisms: Introduction. City 20(2): 204-221.

Wheeler D and Tiefelsdorf M (2005) Multicollinearity and correlation among local regression coefficients in geographically weighted regression. Journal of Geographical Systems 7(2): 161-187.

Wheeler DC (2007) Diagnostic tools and a remedial method for collinearity in geographically weighted regression. Environment and Planning A 39(10): 2464-2481.
Whitehead C and Williams P (2011) Causes and consequences? Exploring the shape and direction of the housing system in the UK post the financial crisis. Housing Studies 26(7-8): 1157-1169.

Williams SM (1992) The need for affordable housing: The constitutional viability of inclusionary zoning. John Marshall Law Review 26: 75.

Wilson A (2013) Entropy in Urban and Regional Modelling (Routledge Revivals). London: Routledge.

Zervas G, Proserpio D and Byers J (2016) The rise of the sharing economy: Estimating the impact of Airbnb on the hotel industry. Boston University School of Management Research Paper (2013-16), Cambridge, MA.

Zhao J, Xu J-H, Mei A-X et al. (2004) A study on the information entropy and fractal dimension of land use structure and form in Shanghai. Geographical Research 23(2): 137-146. 